\title{
Kontribusi Budaya Sekolah dan Motivasi Kerja terhadap Kinerja Guru
}

\author{
N. L Gita Setya Utami I Gst Agung Oka Negara² \\ 1,2 Prodi Pendidikan Guru Sekolah Dasar, Universitas Pendidikan Ganesha \\ Singaraja, Indonesia \\ *e-mail: niluhgitasetyautami12@undiksha.ac.id
}

\begin{abstract}
Abstrak
Perubahan pembelajaran dari tatap muka ke daring telah menyebabkan menurunnya kinerja guru. Penelitian ini bermaksud untuk mengetahui besaran kontribusi budaya sekolah dan motivasi kerja terhadap kinerja guru. Penelitian ini merupakan penelitian ex post facto. Populasi pada penelitian ini adalah guru SD yang berjumlah 32 orang sekaligus sebagai sampel. Teknik pengambilan sampel dengan menggunakan sampling total. Metode pengumpulan data yang digunakan pada penelitian ini yaitu metode kuesioner dan untuk variabel bebas dan pencatatan dokumen untuk variabel terikat. Uji hipotesis menggunakan teknik analisis regresi linier sederhana dan teknik analisis regresi linier ganda setelah uji prasyarat terpenuhi. Hasil penelitian menunjukkan bahwa terdapat kontribusi yang signifikan budaya sekolah terhadap kinerja guru dengan nilai $r_{\text {hitung }}=0,735>r_{\text {tabel }}=0,361$ dan kontribusinya sebesar $54 \%$. Terdapat kontribusi yang signifikan motivasi kerja terhadap kinerja guru dengan nilai $r_{\text {hitung }}=0,738>r_{\text {tabel }}=0,361$ dan kontribusinya sebesar $54 \%$. Secara bersama-sama terdapat kontribusi yang signifikan budaya sekolah dan motivasi kerja terhadap kinerja guru dengan nilai $r_{\text {itung }}=30,988>r_{\text {tabel }}=0,361$ dan kontribusinya sebesar $68 \%$. Hasil penelitian ini disimpulkan bahwa budaya sekolah dan motivasi kerja berkontribusi secara signifikan berkorelasi terhadap kinerja guru. Implikasi dari penelitian ini adalah lingkungan sekolah memegang peranan penting dalam pembentukan budaya sekolah yang positif dan peningkatan motivasi kerja guru, karena untuk mencapai pendidikan yang berkualitas dan bermutu harus didukung oleh budaya sekolah yang baik.
\end{abstract}

Kata kunci: budaya sekolah, motivasi kerja, kinerja guru

\begin{abstract}
The change in learning from face-to-face to online has caused a decline in teacher performance. This study intends to determine the magnitude of the contribution of school culture and work motivation to teacher performance. This research is ex post facto research. The population in this study was 32 elementary school teachers as the sample. The sampling technique used was total sampling. The data collection method used in this research is the questionnaire method and for the independent variable and document recording for the dependent variable. Hypothesis testing using simple linear regression analysis techniques and multiple linear regression analysis techniques after the prerequisite test is met. The results showed that there was a significant contribution of school culture to teacher performance with a value of $r$-count $=0.735>r$-table $=$ 0.361 and the contribution was $54 \%$. There is a significant contribution of work motivation to teacher performance with the value of $r$-count $=0.738>$ r-table $=0.361$ and the contribution is 54\%. Simultaneously, there is a significant contribution of school culture and work motivation to teacher performance with a value of $r$-count $=30.988>r$ table $=0.361$ and the contribution is $68 \%$. The results of this study concluded that school culture and work motivation contributed significantly to the correlation of teacher performance. This research implies that the school environment plays an important role in forming a positive school culture and increasing teacher work motivation because to achieve quality and quality education it must be supported by good school culture.
\end{abstract}

Keywords: school culture, work motivation, teacher performance 


\section{Pendahuluan}

Pendidikan memiliki peranan penting dalam kehidupan manusia. Untuk meraih mutu pendidikan yang baik dipengaruhi oleh kinerja guru dalam melaksanakan tugasnya sehingga kinerja guru menjadi tuntunan penting untuk mencapai keberhasilan pendidikan (Ideswal, 2019). Kinerja merupakan hasil kerja atau prestasi kerja seseorang atau organisasi penampilan dalam melaksanakan tugas (Darmasada, 2020). Faktor yang dapat mempengaruhi kinerja guru ada faktor internal dan eksternal. Faktor internal kinerja guru adalah faktor yang datang dari dalam diri guru yang dapat mempengaruhi kinerajanya, contonya kemampuan, keterampilan, kepribadian, persepsi, motivasi menjadi guru, pengalaman lapangan, dan latang belakang keluarga (Wasito, 2021). Faktor eksternal kinerja guru adalah faktor yang datang dari luar guru yang dapat memepengaruhi kinerjanya yaitu gaji, sarama prasarana, lingkungan kerja fisik serta budaya sekolah.

Budaya sekolah merupakan salah satu faktor yang mempengaruhi kinerja guru. Setiap sekolah penting memiliki budaya atau kultur (Adzkiya, 2020). Budaya sekolah merupakan ciri khas, karakter atau watak dan citra sekolah tersebut di masyarakat luas (Rachmawati, 2018; Silkyanti, 2019). Budaya sekolah adalah komponen yang sangat penting untuk memajukan sekolah dengan memastikan budaya sekolah yang positif. Budaya sekolah adalah sebuah pola perilaku, nilai, kepercayaan, sikap dan prilaku yang merupakan komponen-komponen esensial yang membentuk karakter di dalam pendidikan (Darmawan, 2020; Daryanto, 2015). Budaya sekolah merujuk pada suatu sistem nilai, kepercayaan norma-norma yang diterima, serta dilaksanakan dengan penuh kesadaran budaya sekolah atau aturan-aturan yang di terapkan di sekolah yang didalamnya termasuk guru (Johannes, 2020; Kusumaningrum, 2019). Selain budaya sekolah faktor lain mempengaruhi kinerja guru adalah motivasi kerja. Motivasi adalah sebagai alat dan cara untuk membangkitkan minat atau keinginan untuk berbuat sesuatu yang dianggap memberikan manfaat bagi seseorang maupun orang lain (Ardana, 2020). Maka dari itu motivasi sangat penting karena berhubungan langsung dengan aspek psikologi manusia dan motivasi yang baik akan menghasilkan kerja yang baik pula (Amalda, 2018; Oupen, 2020). Dengan motivasi kerja yang baik diharapkan guru dapat menunjukkan kinerja yang baik dalam memfasilitas proses belajar peserta didik.

Kinerja guru tidak selamanya dapat ajeg dalam sistem pendidikan. Perubahanperubahan yang sering terjadi dapat pula mempengaruhi kinerja guru baik ke arah peningkatan atau penurunan. Penerapan pembelajaran daring diduga telah menyebabkan kinerja guru tidak sama seperti saat pembelajaran tatap muka. Motivasi guru berkurang dalam melaksanakan tugasnya. Budaya mengajar pun ikut berubah yang awalnya tatap muka berubah menjadi pembejaran jarak jauh sehingga turut mempengaruhi motivasi sekaligus kinerja guru. Selain itu, diduga bahwa keterbatasan guru menggunakan teknologi mempengaruhi kurang optimalnya kebiasaan dan motivasi guru. Maka dari itu budaya sekolah dan motivasi kerja terhadap kinerja guru sangatlah berpengaruh. Hal ini didukung oleh hasil-hasil penelitian yang menunjukkan bahwa budaya sekolah dan motivasi kerja berkorelasi dengan kinerja guru (Aryantini, 2018; Nurfasicha, 2020; Soetopo, 2018)

Perbedaan penelitian ini dengan penelitian yang lainnya yaitu, dengan mencari tahu kontribusi budaya sekolah dan motivasi kerja terhadap kinerja guru, karena setiap daerah memiliki budaya tersendiri termasuk budaya sekolah. Budaya sekolah atau aturan-aturan yang diterapkan di sekolah menjadikan guru berhasil dalam menjalankan tugasnya. Selain itu pada situasi pandemic sekarang ini perhatian, kepercayaan dan kepuasan yang diberikan oleh kepala sekolah akan menjadi motivasi tersendiri oleh guru. Penelitian ini penting dilakukan agar mengetahui apakah budaya sekolah dan motivasi kerja masih diterapkan oleh sekolah di masa pandemi. Maka tujuan penelitian ini yaitu untuk mengetahui besaran kontribusi budaya sekolah dan motivasi kerja terhadap kinerja guru di SD Gugus V Abiansemal Tahun Ajaran 2020/2021. 


\section{Metode}

Penelitian ini dilaksanakan pada guru PNS di SD Gugus V Abiansemal. Gugus V Abiansemal digunakan sebagai tempat penelitian karena tempat ini mudah dijangkau dan layak bagi peneliti, dan layak dalam arti belum pernah ada yang melaksanakan penelitian yang sama di SD Gugus V Abiansemal. Penelitian ini dilakukan dengan menggunakan rancangan ex post facto dengan jenis studi penelitian korelasi bertujuan untuk mengetahui korelasi antara dua variabel tanpa manipulasi keadaan variabel serta data yang ada. Ex post facto merupakan penelitian dengan pengamatan yang dilakukan dengan kejadian atau fenomena yang sesudah fakta. Korelasi adalah hubungan yang bersifat asosiatif Variabel dalam penelitian ini terdiri dari budaya sekolah $\left(X_{1}\right)$ sebagai variabel bebas, motivasi kerja sebagai $\left(\mathrm{X}_{2}\right)$ sebagai variabel bebas dan kinerja guru $(\mathrm{Y})$ sebagai variabel terikat. Adapun gambar variabel penelitian ini sebagai berikut:

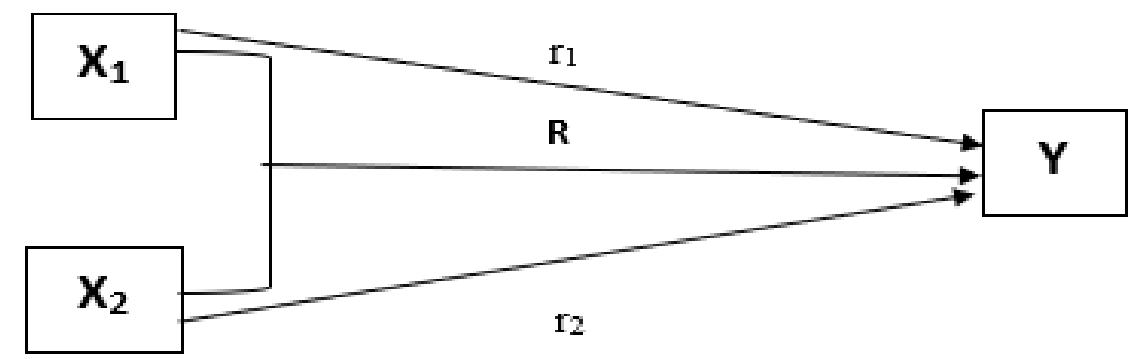

Gambar 1. Pradigma Ganda dengan Dua Variabel Independen

Populasi dan sampel pada penelitian ini adalah 32 orang guru pada SD Gugus V Abiansemal yang terdiri dari 6 sekolah dasar, dengan rincian yaitu: SD No. 1 Abiansemal sebanyak 6 orang; SD No. 2 Abiansemal sebanyak 5 orang; SD No. 3 Abiansemal sebanyak 6 orang; SD No. 4 Abiansemal sebanyak 3 orang; SD No. 5 Abiansemal sebanyak 6 orang dan SD No. 6 Abiansemal sebanyak 6 orang. Teknik pengambilan sampel pada penelitian ini yaitu sampling total, dimana seluruh anggota populasi dijadikan sampel karena jumlah populasi relatif kecil. Metode pengumpulan data yang digunakan pada penelitian ini adalah metode kuesioner untuk variabel bebas dan pencatatan dokumen untuk variabel terikat. Untuk dapat memperoleh data dari variabel terikat yakni kinerja guru digunakan pengisian kuesioner dan teknik pencatatan dokumen. Kuesioner/angket dan pencatatan dokumen diperlukan untuk sumber data penelitian. Data yang dianalisis dalam penelitian ini adalah data mengenai kinerja guru, budaya sekolah dan motivasi kerja. Dalam penelitian ini analisis data yang digunakan adalah analisis statistik deskriptif dan inferensial karena data yang diperoleh dalam penelitian ini berupa data angka kuantitatif. Metode analisis data dilakukan untuk menguji apakah data yang telah didapatkan memenuhi syarat untuk dianalisis dengan teknik analisis regresi linier sederhana dan teknik analisis regresi linier ganda. Adapun indikator-indikator yang digunakan dalam penyusunan instrument angket adalah sebagai berikut.

Tabel 1. Indikator Budaya Sekolah

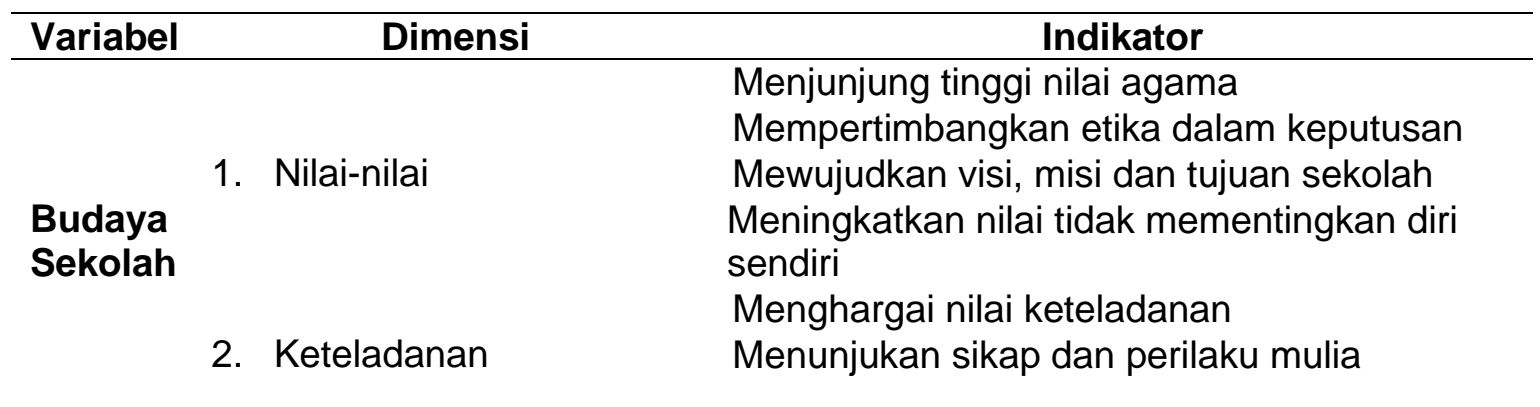




\begin{tabular}{|c|c|c|}
\hline Variabel & Dimensi & Indikator \\
\hline \multirow{3}{*}{\multicolumn{2}{|c|}{ 3. Tanggung jawab }} & Memiliki dedikasi tinggi \\
\hline & & Memiliki komitmen tinggi \\
\hline & & Menciptakan rasa kekeluargaan, \\
\hline \multirow{2}{*}{\multicolumn{2}{|c|}{ 4. Kebersamaan/Intimasi }} & kerukunan, keharmonisan \\
\hline & & Menjalin hubungan yang akrab \\
\hline \multirow{2}{*}{\multicolumn{2}{|c|}{ 5. Otonomi individu }} & Memberikan kebebasan \\
\hline & & Mengembangkan kemampuan \\
\hline \multirow{2}{*}{\multicolumn{2}{|c|}{ 6. Norma/tata aturan }} & Menghormati norma \\
\hline & & Menciptakan tata tertib/peraturan \\
\hline \multirow{2}{*}{\multicolumn{2}{|c|}{ 7. Dukungan }} & Mendukung adanya inisiatif \\
\hline & & Mendapat perhatian dan penghargaan \\
\hline \multirow{2}{*}{\multicolumn{2}{|c|}{ 8. Identitas }} & Memiliki sikap ramah \\
\hline & & Mengenal sesuatu dengan baik \\
\hline \multirow{2}{*}{\multicolumn{2}{|c|}{ 9. Hadiah performansi }} & $\begin{array}{l}\text { Memberikan penghargaan untuk suatu } \\
\text { prestasi }\end{array}$ \\
\hline & & Menghormati perbedaan \\
\hline \multirow{3}{*}{\multicolumn{2}{|c|}{ 10. Toleransi konflik }} & Memiliki kebranian menanggung resiko \\
\hline & & Mencoba sesuatu yang baru \\
\hline & & Melakukan upacara bendera \\
\hline \multirow{2}{*}{\multicolumn{2}{|c|}{ 11. Upacara simbolik }} & Melakukan upacara keagamaan \\
\hline & & $\begin{array}{l}\text { Melakukan peringatan hari besar nasional } \\
\text { dan hari lainnya }\end{array}$ \\
\hline
\end{tabular}

Tabel 2. Indikator Motivasi Kerja

No Dimensi

1. Motivasi Internal

2. Motivasi Eksternal

\section{Indikator}

a. Meningkatkan prestasi dari pekerjaan sebelumnya

b. Pengakuan atau penghargaan yang diterima.

c. Pekerjaan itu sendiri.

d. Tanggung jawab dalam melaksanakan tugas dari dalam diri

e. Mengembangan potensi

a. Hubungan antar pribadi

b. Kondisi kerja secara kondusif

c. Kualitas supervise dengan teknik yang tepat.

d. Kebijakan administrasi

e. Gaji atau penghasilan

Penggunaan kuesioner dapat mengumpulkan informasi yang dibutuhkan dengan cara tidak memberikan pertanyaan atau jawaban secara langsung. Bentuk kuesioner yang digunakan adalah kuesioner tertutup. Pada kuesioner dalam bentuk tertutup, alternatif jawaban sudah ditentukan terlebih dahulu. Responden memilih antara alternatif yang telah disediakan. Skala likert yang digunakan untuk mengukur sikap, pendapat dan persepsi seseorang tentang fenomena sosial. Jawaban disetiap item instrumen yang menggunakan skala likert mempunyai gradasi yang sangat positif sampai sangat negatif, yang berupa kata-kata sangat setuju, setuju, tidak setuju, sangat tidak setuju.

\section{Hasil dan Pembahasan}

Data mengenai kinerja guru di SD Gugus V Abiansemal diperoleh melalui pencatatan dokumen, dokumen tersebut adalah penilaian kinerja guru (PKG) dengan meminta ijin kepada kepala sekolah di Gugus V Abainsemal. Pencatatan dokumen sesuai dengan jumlah responden yaitu 32 responden. Adapun hasil deskripsi data penilaian 
kinerja guru, budaya sekolah dan motivasi kerja terhadap kinerja guru sebagai sebagai berikut. Hipotesis pertama yang diuji dalam penelitian ini adalah $\mathrm{H}_{0}$ yang menyatakan bahwa tidak terdapat pengaruh yang signifikan budaya sekolah terhadap kinerja guru pada SD Gugus V Abiansemal. Pengaruh budaya sekolah terhadap kinerja guru dicari dengan menggunakan analisis regresi linier sederhana dengan mencarai nilai $a$ dan $b$ terlebih dahulu. Setelah mendapatkan nilai a dan b maka dinyatakan melalui persamaan regresi yaitu $\widehat{Y}=64,70+0,19 \times 1$. Sebelum persamaan regresi dilanjutkan, maka dilakukan uji linieritas dan uji signifikansi. Hasil uji signifikansi dan uji linieritas dipaparkan dalam Tabel sebagai berikut.

Tabel 3. Hasil Uji Linearitas Budaya Sekolah terhadap Kinerja Guru

\begin{tabular}{cccccc}
\hline Sumber Variasi & JK (SS) & dk (df) & RJK (MS) & F hitung & F tabel \\
\hline Total & 246515 & 32 & 7703,59 & - & - \\
Koefisien (a) & 246226,53 & 1 & - & & \\
Regresi (b|a) & 145,46 & 1 & 145,5 & 37,97 & 4,17 \\
Sisa (residu) & 114,94 & 30 & 3,83 & & \\
Tuna Cocok & 63,34 & 16 & 3,96 & \multirow{2}{*}{1,07} & 2,37 \\
Galat (error) & 51,6 & 14 & 3,69 & \\
\hline
\end{tabular}

Dalam Tabel 3 pada signifikansi $5 \%$ dengan dk pembilang 1 dan dk penyebut 30 maka dapat diketahui $F_{\text {tabel }}=4,17$. Kriteria yang digunakan dalam membandingkan adalah jika $F_{\text {hitung }} \geq F_{\text {tabel }}$ maka $F$ regresi signifikan, dengan demikian pada tabel tersebut didapat Fhitung $=37,97>$ Ftabel $=4,17$ pada taraf signifikansi $5 \%$ maka $\mathrm{F}$ regresi tersebut signifikan. Selanjutnya, uji prasyarat yakni uji linieritas dengan kreteria $F_{\text {hitung }}<F_{\text {tabel }}$ dengan taraf signifikan $5 \%$ dan dk pembilang 16 serta dk penyebut 14 sehingga regresi $Y$ atas $\mathrm{X}$ adalah linier. Hasil perhitungan pada tabel tersebut menujukkan bahwa Fhitung $=$ $1,07<$ Ftabel $=2,37$ maka regresi dinyatakan linier. Berdasarkan hasil uji signifikansi dan uji linieritas tersebut diketahui persamaan regresi $\widehat{Y}=64,70+0,19 X 1$ signifikan dan linier. Persamaan regresi yang telah didapat berarti bahwa setiap kenaikan 1 kali satuan budaya sekolah menyebabkan kenaikan 0,19 nilai kinerja guru pada konstanta 64,70.

Jika $X=50$, Maka:

$$
\begin{aligned}
& \widehat{Y}=64,70+0,19(50) \\
& \widehat{Y}=64,70+9,5 \\
& \widehat{Y}=74,2
\end{aligned}
$$

Persamaan regresi tersebut digambarkan dengan garis regresi pada gambar 2 .

Kekuatan hubungan antara budaya sekolah $\left(X_{1}\right)$ dengan kinerja guru $(Y)$ ditunjukan oleh koefisien kolerasi $\left(r_{x y}\right)$ dengan kriteria rhitung rtabel. Ketentuan bila rhitung lebih kecil dari rtabel, maka $\mathrm{H}_{0}$ diterima dan $\mathrm{H}_{\mathrm{a}}$ ditolak". Berdasarkan uji koefisien kolerasi pada taraf signifikan $5 \%$ dengan $\mathrm{dk}=30$ diperoleh rtabel $=$ 0,361 dengan demikian rhitung $=0,735>$ rtabel $=0,361$ ini berarti nilai koefisien kolerasi tersebut signifikan, yang menyatakan bahwa kolerasi budaya sekolah dengan kinerja guru memiliki hubungan positif. Koefisien determinasi adalah nilai yang digunakan untuk mengukur besarnya kontribusi variabel independen $\left(X_{1}\right)$ terhadap variasi variabel dependen $(Y)$. Koefisien determinasi yang diperoleh adalah $R^{2}=0,540$ dan kontribusinya sebesar $54 \%$ variasi kinerja guru ditentukan oleh budaya sekolah, dengan kata lain variabel y lainnya disebabkan oleh faktor lain.

Hipotesis kedua yang diuji dalam penelitian ini adalah $\mathrm{H}_{0}$ yang menyatakan bahwa tidak terdapat pengaruh yang signifikan motivasi kerja terhadap kinerja guru di SD Gugus V Abiansemal. Pengaruh motivasi kerja terhadap kinerja guru dicari dengan menggunakan regresi analisis linier sederhana dengan mencari nilai $a$ dan $b$ terlebih dahulu. Setelah mendapatkan nilai a dan b maka dinyatakan melalui persamaan 
regresi yaitu $\hat{Y}=62,79+0,20 \mathrm{X}_{2}$. Sebelum persamaan regresi dilanjutkan, maka dilakukan uji linieritas dan uji signifikansi. Hasil uji signifikansi dan uji linieritas dipaparkan dalam Tabel sebagai berikut.

Tabel 4. Hasil Uji Linearitas Motivasi Kerja terhadap Kinerja Guru

\begin{tabular}{cccccc}
\hline Sumber Variasi & JK (SS) & dk (df) & RJK (MS) & F hitung & F tabel \\
\hline Total & 246515 & 32 & 7703,59 & - & - \\
Koefisien (a) & 246226,53 & 1 & - & & \\
Regresi (b|a) & 147,88 & 1 & 147,9 & 31,54 & 4,17 \\
Sisa (residu) & 140,59 & 30 & 4,69 & & \\
Tuna Cocok & 80,49 & 16 & 5,03 & 1,17 & 2,37 \\
Galat (error) & 60,1 & 14 & 4,29 & & \\
\hline
\end{tabular}

Dalam Tabel 4 pada signifikansi $5 \%$ dengan dk pembilang 1 dan dk penyebut 30 maka dapat diketahui $F_{\text {tabel }}=4,17$. Kriteria yang digunakan dalam membandingkan adalah jika $F_{\text {hitung }} \geq F_{\text {tabel }}$ maka $F$ regresi signifikan , dengan demikian pada tabel tersebut didapat Fhitung $=31,54>$ Ftabel $=4,17$ pada taraf signifikansi $5 \%$ maka $\mathrm{F}$ regresi tersebut signifikan. Selanjutnya, uji prasyarat yakni uji linieritas dengan kreteria $F_{\text {hitung }}<F_{\text {tabel }}$ dengan taraf signifikan $5 \%$ dan dk pembilang 16 serta dk penyebut 14 sehingga regresi $Y$ atas $X$ adalah linier. Hasil perhitungan pada tabel tersebut menujukkan bahwa Fhitung $=$ $1,17<$ Ftabel $=2,37$ maka regresi dinyatakan linier. Berdasarkan hasil uji signifikansi dan uji linieritas tersebut diketahui persamaan regresi $\widehat{Y}=62,79+0,20 \times 2$ signifikan dan linier. Persamaan regresi yang telah didapat berarti bahwa setiap kenaikan 1 kali satuan budaya sekolah menyebabkan kenaikan 0,19 nilai kinerja guru pada konstanta 62,79.

Jika $X=50$, Maka:

$$
\begin{aligned}
& \widehat{Y}=62,79+0,20(50) \\
& \widehat{Y}=62,79+10 \\
& \widehat{Y}=72,79
\end{aligned}
$$

Persamaan regresi tersebut digambarkan dengan garis regresi pada gambar 3.

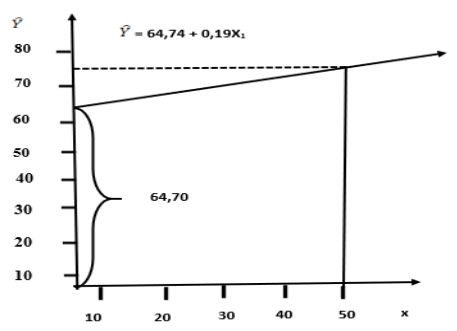

Gambar 2. Garis regresi $\widehat{Y}=64,70+$ $0,19 X_{1}$

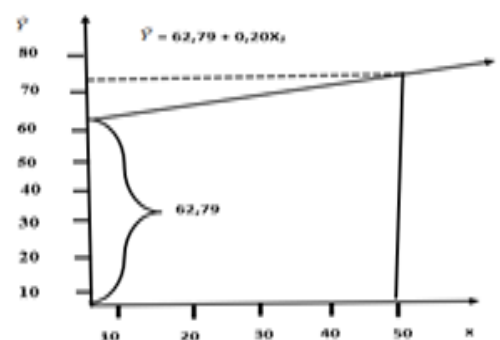

Gambar 3. Garis regresi $\widehat{Y}=62,79+$ $0,20 \mathrm{X}_{2}$

Kekuatan hubungan motivasi kerja $\left(\mathrm{X}_{2}\right)$ dengan kinerja guru $(\mathrm{Y})$ ditunjukan oleh koefisien $\left(r_{x y}\right)$ dengan kriteria $r_{\text {hitung }} r_{\text {tabel. }}$. Berdasarkan uji koefisien kolerasi pada taraf signifikansi $5 \%$ dengan $\mathrm{dk} 30$ diperoleh $r_{\text {tabel }}=0,361$ dengan demikian $r_{\text {hitung }}=0,738>r_{\text {tabel }}$ $=0,361$ ini berarti nilai koefisien kolerasi tersebut signifikan, yang menyatakan bahwa kolerasi motivasi kerja dengn kinerja guru memiliki hubungan yang positif. Koefisien determinasi yang diperoleh adalah $\mathrm{R}^{2}=0,544$ dan kontribusinya sebesar $54 \%$ Variasi kinerja guru ditentukan oleh motivasi kerja, dengan kata lain variabel y lainnya 
disebabkan oleh faktor lain. Hipotesis ketiga yang diuji dalam penelitian ini adalah $\mathrm{H}_{0}$ yang menyatakan bahwa tidak terdapat pengaruh yang signifikan budaya sekolah dan motivasi kerja terhadap kinerja guru di SD Gugus V Abiansemal. Pengaruh budaya sekolah dan motivasi kerja terhadap kinerja guru dicari dengan menggunakan analisis regresi linier ganda dengan mencari nilai $a, b_{1}$, dan $b_{2}$ terlebih dahulu. Setelah mendapatkan nilai $a, b 1$ dan b2 maka dinyatakan melalui persamaan regresi yaitu $\hat{Y}=58,420+0,118 X 1+$ $0,124 X_{2}$. Sebelum persamaan regresi dilanjutkan, maka dilakukan uji signifikansi. Hasil uji signifikansi sebagai uji prasyarat dipaparkan dalam Tabel sebagai berikut.

Tabel 5. Hasil Uji Linearitas Budaya Sekolah dan Motivasi Kerja terhadap Kinerja Guru

\begin{tabular}{cccccc}
\hline Sumber Variasi & JK (SS) & dk (df) & RJK (MS) & F hitung & F tabel \\
\hline Total & 259,990 & 31 & - & - & - \\
Regresi (b|a) & 177,114 & 2 & 88,557 & 30,988 & 3,328 \\
Sisa (residu) & 82,876 & 29 & 2,858 & & \\
\hline
\end{tabular}

Dalam Tabel 5 pada signifikansi $5 \%$ dengan dk pembilang 2 dan dk penyebut 29 maka dapat diketahui $F_{\text {tabel }}>3,328$. Kriteria yang digunakan dalam membandingkan adalah jika Fhitung $\geq$ Ftabel maka $\mathrm{F}$ Regresi signifikan, dengan demikian pada tabel tersebut didapat Fhitung $=30,988>$ Ftabel $=3,328$ pada taraf signifikansi $5 \%$ maka $\mathrm{F}$ regresi tersebut signifikan. Berdasarkan hasil uji signifikansi tersebut diketahui persamaan regresi $\widehat{Y}=58,37+0,118 \mathrm{X} 1+0,124 \mathrm{X} 2$ signifikan. Persamaan regresi yang telah didapat berarti bahwa setiap kenaikan 1 kali satuan budaya sekolah dan 1 kali satuan motivasi kerja menyebabkan kenaikan budaya sekolah 0,118 dan motivasi kerja 0,124 nilai kinerja guru pada konstanta 58,37 .

$$
\begin{aligned}
\text { Jika } X & =50, \text { maka: } \\
\widehat{Y} & =58,37+0,118(50)+0,124(50) \\
\widehat{Y} & =58,37+5,9+6,2 \\
\widehat{Y} & =70,47
\end{aligned}
$$

Persamaan regresi tersebut digambarkan dengan garis regresi sebagai berikut.

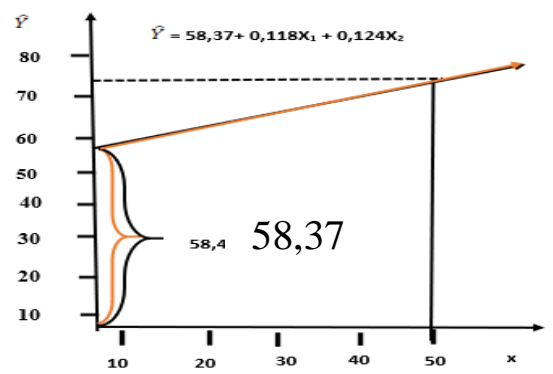

Gambar 4. Garis Regresi $\widehat{Y}=58,37+0,118 \mathrm{X}_{1}+0,124 \mathrm{X}_{2}$

Kekuatan hubungan antara budaya sekolah (X1) dan motivasi kerja (X2) dengan kinerja guru(Y) ditunjukan oleh koefisien korelasi $(r x y)$ dengan kriteria rhitung $>$ rtabel. Berdasarkan uji koefisien korelasi pada taraf signifikan $5 \%$ dengan $\mathrm{dk}=29$ diperoleh $\mathrm{r}_{\text {tabel }}$ $=0,361$ dengan demikian $r_{\text {hitung }}=30,988>r_{\text {tabel }}=0,361$ ini berarti nilai koefisien korelasi tersebut signifikan, yang menyatakan bahwa korelasi budaya sekolah dan motivasi kerja secara bersama- sama dengan kinerja guru memiliki hubungan positif. Koefisien determinasi adalah nilai yang dugunakan untuk mengukur besarnya kontribusi variabel independent $\left(\mathrm{X}_{1}\right.$ dan $\left.\mathrm{X}_{2}\right)$ secara bersama-sama terhadap variasi variabel dependen $(\mathrm{Y})$. 
Koefisien determinasi yang diperoleh adalah $\mathrm{R}^{2}=0,681$ dan kontribusinya sebesar $68 \%$ variasi kinerja guru ditentukan oleh budaya sekolah dan motivasi kerja , dengan kata lain variabel y lainnya disebabkan oleh faktor lain.

Pengujian hipotesis pertama dengan analisis regresi sederhana diperoleh persamaan regresi $\hat{Y}=64,70+0,19 X 1$ signifikan dan linier. Persamaan regresi yang telah didapat berarti bahwa setiap kenaikan 1 kali satuan budaya sekolah menyebabkan kenaikan 0,19 nilai kinerja guru pada konstanta 64,70 , sehingga $\mathrm{HO}$ yang menyatakan tidak terdapat pengaruh yang signifikan budaya sekolah terhadap kinerja guru di SD Gugus V Abiansemal ditolak dan Ha diterima. Hasil analisis data diperoleh koefisien determinasi R2 $=0,540$ dan kontribusinya sebesar $54 \%$. Hal ini berarti terdapat pengaruh yang signifikan budaya sekolah terhadap kinerja guru di SD Gugus V Abiansemal dan kontribusinya sebesar $54 \%$. Berdasarkan hal tersebut, dalam penelitian ini menunjukkan bahwa budaya sekolah dan motivasi kerja berhubungan dengan kinerja guru. Tingginya budaya sekolah dan motivasi kerja yang dimiliki oleh guru memiliki pengaruh yang baik dalam mencapai kinerja. Hal tersebut dikarenakan guru yang memiliki budaya sekolah yang positif otomatis kepercayaan norma-norma yang ada di sekolah tersebut akan diterapkan dengan baik sesuai norma yang ada. Budaya sekolah di pengaruhi oleh faktor yaitu antusiasme guru dalam mengajar dan penguasaan materi yang diajarkan, kedisiplinan sekolah, dan proses belajar mengajar, jadwal yang ditepati, sikap guru terhadap siswa, maupun kepemimpinan kepala sekolah. Hasil penelitian ini sesuai dengan hasil penelitian yang dilakukan oleh Purwoko (2018) Hasil yang diperoleh yaitu terdapat pengaruh yang positif dan signifikan budaya sekolah terhadap kinerja guru dengan sumbangan efektifnya $16,1 \%$.

Pengujian hipotesis kedua dengan analisis regresi sederhana diperoleh persamaan regresi $\hat{Y}=62,79+0,20 \mathrm{X}_{2}$ signifikan dan linier. Persamaan regresi yang telah didapat berarti bahwa setiap kenaikan 1 kali satuan motivasi kerja menyebabkan kenaikan 0,20 nilai kinerja guru pada konstanta 62,79 , sehingga $\mathrm{H} 0$ yang menyatakan tidak terdapat pengaruh yang signifikan motivasi kerja terhadap kinerja guru di SD Gugus $\checkmark$ Abiansemal ditolak dan Ha diterima. Hasil analisis data diperoleh koefisien determinasi $\mathrm{R} 2=0,544$ dan kontribusinya sebesar $54 \%$. Hal ini berarti terdapat pengaruh yang signifikan budaya sekolah terhadap kinerja guru di SD Gugus V Abiansemal dan kontribusinya sebesar $54 \%$. Motivasi kerja merupakan ciri seseorang yang mempunyai harapan tinggi untuk mencapai keberhasilan. Bagi para guru motivasi kerja harus dimiliki, harus diperjuangkan dan menjadi sesuatu yang dibanggakan. Selain itu, guru yang memiliki motivasi kerja yang tinggi cenderung memperoleh prestasi. Membangkitkan motivasi kerja guru dapat memberikan pengaruh yang cukup besar terhadap prestasi kerja. Maka dirasa sangat penting untuk meningkatkan budaya sekolah dan motivasi kerja guru guna mengoptimalkan kinerja guru. Hasil penelitian ini sesuai dengan hasil penelitian yang dilakukan oleh Nartha (2017) Hasil yang diperoleh yaitu terdapat Kontribusi yang signifikan motivasi kerja terhadap kinerja guru dengan kontribusi sebesar $38,4 \%$ dan sumbangan efektifnya sebesar $23,40 \%$.

Pengujian hipotesis ketiga dengan analisis regresi ganda diperoleh persamaan regresi $=58,37+0,118 \mathrm{X} 1+0,124 \mathrm{X} 2$ signifikan. Persamaan regresi yang telah didapat berarti bahwa setiap kenaikan 1 kali satuan budaya sekolah dan 1 skor motivasi kerja menyebabkan kenaikan budaya sekolah 0,118 dan motivasi kerja 0,124 nilai kinerja guru pada konstanta 58,37, sehingga $\mathrm{HO}$ yang menyatakan tidak terdapat pengaruh yang signifikan budaya sekolah dan motivasi kerja terhadap kinerja guru di SD Gugus V Abiansemal ditolak dan Ha diterima. Hasil analisis data diperoleh koefisien determinasi $\mathrm{R} 2=0,681$ dan kontribusinya sebesar $68 \%$. Maka, hal ini berarti terdapat pengaruh yang signifikan budaya sekolah dan motivasi kerja terhadap kinerja guru di SD Gugus V Abiansemal dan kontribusinya sebesar $68 \%$. Hal ini berarti bahwa budaya sekolah yang positif dan motivasi kerja tinggi mengarahkan guru agar mampu meraih kinerja lebih optimal dan mampu meningkatkan kinerja dengan baik. 
Hasil perhitungan korelasi budaya sekolah terhadap kinerja guru terdapat korelasi yang signifikan. Dapat dijelaskan bahwa budaya sekolah yang kondusif dengan memperhatikan nilai-nilai, etika, aturan, keteladan, kebersamaan, penghargaan, dan toleransi memberikan sumbangan terhadap kinerja guru. Peningkatan kinerja guru tidak semata karena finansial namun budaya yang terbangun di sekolah juga memberikan kontribusi. Budaya sekolah akan memberikan kenyamanan guru dalam bekerja sehingga meningkatkan kinerja guru (Vinet \& Zhedanov, 2017). Semakin baik susana yang tercipta akan mengakibatkan pencapaian kinerja organisasi secara maksimal (Ningsih, 2016). Terjadinya perubahan dalam lingkungan kerja tentu akan meningkatnya mutu sekolah yang akan berdampak positif terhadap kinerja guru (Ansori, 2019). Dengan adanya perubahan budaya sekolah yang kondusif tentunya dapat memberikan kenyamanan kepada guru-guru untuk bekerja secara optimal.

Korelasi motivasi kerja dengan kinerja guru menunjukkan hasil yang signifikan. Pemberian motivasi akan membuat kinerja guru semakin meningkat. Pemberian motivasi sangat erat kaitannya dengan kepemimpinan kepala sekolah karena kepala sekolah memiliki kekuatan untuk selalu memotivasi para guru. Kepala sekolah yang memiliki jiwa kepemimpinan yang baik, tenang, dan tegas kepada bawahannya dapat berpengaruh terhadap kinerja guru (Priyono et al., 2018). Selain itu dari hasil penelitian menunjukkan bahwa kepemimpinan, teladan, lingkungan kerja yang nyaman, secara langsung memiliki pengaruh signifikan terhadap kinerja guru sehingga akan mendukung peningkatan mutu pendidikan yang ada disekolah (Prasetyo, 2020; Siagian, 2018). Ini artinya bahwa dengan kempimpinan, teladan, lingkungan kerja merupakan hal memiliki kaitan erat dengan motivasi guru. Teladan yang diberikan oleh kepada sekolah tentu akan semakin memotivasi guru untuk selalui berkinerja yang baik.

Kontribusi budaya sekolah dan motivasi kerja secara bersama-sama tehadap kinerja guru adalah sebesar $68 \%$. Hasil ini menunjukkan bahwa masih terdapat sekitar $32 \%$ kinerja dipengaruhi oleh faktor-fakto lain. Baik faktor internal maupun eksternal masing-masing mempunyai dampak terhadap kinerja guru. Faktor internal kinerja guru yaitu faktor yang datang dari dalam diri guru yang dapat memengaruhi kinerja. Contohnya seperti (1) kemampuan, (2) keterampilan, (3) kepribadian, (4) persepsi, (5) motivasi, (6) menjadi guru, (7) latar belakang keluarga serta pengalaman lapangan. Sedangkan Faktor eksternal kinerja guru yaitu faktor yang dating dari luar guru yang memengaruhi kinerjanya diantaranya seperti (1) gaji, (2) sarana (3) prasarana (4) lingkungan kerja fisik. Faktor eksternal sangat penting untuk diperhatikan karena pengaruhnya cukup kuat terhadap guru. Faktor tersebut akan terus memengaruhi guru sehingga akan lebih dominan dalam menentukan seberapa baik kinerja guru. Hasil penelitian ini juga didukung oleh hasil penelitian lainnya bahwa budaya sekolah dan motivasi kerja berkorelasi positif terhadap kinerja guru (Komarudin, 2018; Zulkarnaen, 2020). Budaya sekolah dan motivasi kerja baik secara parsial maupun simultan berpengaruh terhadap kinerja guru. Keterampilan memimpinan juga merupakan salah satu kinerja guru yang dapat dipengaruhi oleh budaya sekolah (Yusof et al., 2016).

Sebagai implikasi dari hasil penelitian ini adalah bahwa lingkungan sekolah memegang peranan penting dalam pembentukan budaya sekolah yang positif dan peningkatan motivasi kerja guru, karena mencapai pendidikan yang berkualitas dan bermutu bagi suatu negara, maka dari itu sekolah harus menerapkan kinerja guru yang baik. Karena guru adalah figur yang menempati posisi memegang peranan penting dalam pendidikan. Guru dituntut memiliki kinerja yang mampu memberikan dan merealisasikan harapan dan keinginan semua pihak terutama masyarakat umum yang telah mencapai sekolah dan guru dalam membina anak didk. Karena pendidikan mempunyai peran yang sangat menentukan kehidupan seseorang, tidak hanya bagi perkembangan dan perwujudan dari individu tetapi juga bagi perkembangan suatu bangsa dan negara. Kemajuan suatu kebudayaan tergantung dari bagaimana kebudayaan tersebut mengenali, menghargai, dan memanfaatkan sumber daya manusianya. Pada awalnya budaya sekolah dibentuk dalam jaringan yang sifatnya formal. Berkaitan dengan nilai, norma, dan aturan ditentukan dan ditetapkan pihak sekolah sebagai panduan bagi warga 
sekolah dalam berfikir, bersikap dan bertindak. Maka dari itu motivasi guru dalam pendidikan sangat penting, jika motivasi yang dimiliki oleh guru sangat baik maka kualitas sekolah semakin meningkat dan menghasilkan kerja yang sangat baik. Dengan demikian, peran guru sangat penting dalam pembentukan budaya sekolah positif dan motivasi kerja yang tinggi guna untuk mengoptimalkan kinerja guru.

\section{Simpulan}

Terdapat pengaruh yang signifikan antara budaya sekolah terhadap kinerja guru di SD Gugus V Abiansemal. Terdapat pengaruh yang signifikan antara motivasi kerja terhadap kinerja guru di SD Gugus V Abiansemal. Secara bersama-sama terdapat pengaruh yang signifikan antara budaya sekolah dan motivasi kerja terhadap kinerja guru di SD Gugus V Abiansemal. Sebagai tindak lanjut dari hasil penelitian, maka penelitian ini disarankan kepada guru disarankan untuk selalu menunjukkan kinerja yang terbaik didalam menjalankan kewajibannya sebagai pendidik di sekolah. Selain itu guru juga disarankan untuk selalu mampu meningkatkan motivasi dirinya dalam bekerja, sehingga berdampak positif terhadap budaya organisasi dan kinerja guru.

\section{Daftar Pustaka}

Adzkiya, A. (2020). Sekolah dan Komitmen Profesional Guru Terhadap Kinerja Guru ( Studi Kasus Di Mts Ma' Arif Nu Kabupaten Banyumas ). Jurnal Ekonomi, Bisnis Dan Akuntansi, 22.

Amalda, N. (2018). Pengaruh motivasi kerja guru, disiplin kerja guru, dan kedisiplinan siswa terhadap prestasi belajar siswa. Jurnal Akuntabilitas Manajemen Pendidikan, 6(1), 11. https://doi.org/10.21831/amp.v6i1.7515.

Ansori. (2019). Pengaruh Kompetensi dan Lingkungan Kerja terhadap Kinerja Guru SMA Negeri 1 Kuantan Hilir. Eko Dan Bisnis (Riau Economics and Reviewe), 10(2), 261-271.

Ardana, P. (2020). Jurnal Administrasi Pendidikan Indonesia Kontribusi Sertifikasi Guru, Motivasi Kerja dan Supervisi Akademik Kepala Sekolah. Jurnal Administrasi Pendidikan Indonesia, 11(1), 42-53.

Aryantini, N. P. (2018). Kontribusi Implementasi Manajemen Sekolah Berbasis Kecamatan Sukasada Kabupaten Buleleng. Jurnal Administrasi Pendidikan, 9(2), 99-110.

Darmasada, I. K. N. (2020). Upaya Peningkatan Prestasi Kinerja Guru Melalui Teknik Meeting Kepala Sekolah. Indonesian Journal Of Educational Research And Review, 3(1), 117-124.

Darmawan, A. (2020). Pengaruh Penggunaan Kahoot Terhadap Hasil Belajar Materi Ruang Lingkup Biologi. EduTeach : Jurnal Edukasi Dan Teknologi Pembelajaran, 1(2), 91-99. https://doi.org/10.37859/eduteach.v1i2.1974.

Daryanto. (2015). Pengelolaan Budaya dan Iklim Sekolah. Gava Media.

Ideswal. (2019). Kontribusi Iklim Sekolah dan Kepemimpinan Kepala Sekolah terhadap Kinerja Guru Sekolah Dasar. Jurnal Basicedu, 3(2), 524-532.

Johannes, N. Y. (2020). Implementasi Budaya Sekolah Dalam Mewujudkan Pendidikan Karakter di SD Negeri 19 Ambon. Jurnal Pedagogika Dan Dinamika Pendidikan, $8(1), 1$.

Komarudin. (2018). Pengaruh Motivasi Kerja dan Budaya Kerja Guru Terhadap Kinerja Guru SMK Negeri Se-Lampung Timur. Jurnal Lentera Pendidikan Pusat Penelitian Lppm UM Metro, 3(2), 47-57. https://doi.org/10.21067/jrpe.v3i2.3806.

Kusumaningrum, D. E. (2019). Budaya Sekolah Dan Etika Profesi: Pengukuran Pemberdayaan Sumber Daya Manusia Sekolah Dengan Pendekatan Soft System Methodology. Jurnal Administrasi Dan Manajemen Pendidikan, 2(3), 090-097. https://doi.org/10.17977/um027v2i32019p90. 
Ningsih, P. (2016). Pengaruh Komitmen, Kompetensi, Dan Lingkungan Kerja Terhadap Kinerja Guru Di Kecamatan Pasangkayu Kabupaten Mamuju Utara (Study Kasus pada SMA Negeri 1 Pasangkayu dan MA DDI Pasangkayu). Kataogis, 5(7), 181190.

Nurfasicha, I. (2020). Pengaruh Kepemimpinan Transformasional Kepala Sekolah, Budaya Sekolah, Dan Lingkungan Sekolah Terhadap Kinerja Guru Di Mi Islamiyah Wareng, Butuh, Purworejo, Jawa Tengah. Ibtida, Vol. 1 No(1), 67-89.

Oupen, S. M. (2020). Kontribusi Kepemimpinan Transformasional, Budaya Organisasi, Disiplin Kerja, dan Motivasi Kerja, Terhadap Komitmen Organisasional Guru SD. Jurnal Administrasi Pendidikan Indonesia, 11(1), 34-43. https://doi.org/10.23887/japi.v1111.3167.

Prasetyo, E. B. (2020). Pengaruh motivasi, kepemimpinan dan lingkungan kerja terhadap kinerja guru melalui kompetensi guru SMK Negeri Sekar Kabupaten bojonegoro. Jurnal Mitra Pendidikan, 2(1), 11-22.

Priyono, B. H., Qomariah, N., \& Winahyu, P. (2018). Pengaruh Gaya Kepemimpinan, Motivasi Guru Dan Lingkungan Kerja Fisik Terhadap Kinerja Guru Sman 1 Tanggul Jember. Jurnal Manajemen Dan Bisnis Indonesia, 4(2), 144. https://doi.org/10.32528/jmbi.v4i2.1758.

Rachmawati, W. (2018). Budaya Sekolah Berbasis Ketarunaan Dalam Pembentukan Karakter Peserta Didik. Jurnal Administrasi Dan Manajemen Pendidikan, 1, 410418. https://doi.org/10.17977/um027v1i42018p410.

Siagian. (2018). Pengaruh Gaya Kepemimpinan Dan Lingkungan Kerja Terhadap Kinerja Karyawan Dengan Kepuasan Kerja Sebagai Variabel Intervening. Maneggio: Jurnal Ilmiah Magister Manajemen, 1(1), 59-70. https://doi.org/10.30596/maneggio.v1i1.2241.

Silkyanti, F. (2019). Analisis Peran Budaya Sekolah yang Religius dalam Pembentukan Karakter Siswa. Indonesian Values and Character Education Journal, 2(1), 36. https://doi.org/10.23887/ivcej.v2i1.17941.

Soetopo, I. (2018). Pengaruh Gaya Kepemimpinan Transformasional, Karakteristik Individu, Lingkungan Kerja Terhadap Motivasi Kerja dan Kinerja Guru SMK Negeri 1 Tambelangan Sampang. Jurnal Ilmu Ekonomi \& Manajemen, 05, 21-31.

Vinet, L., \& Zhedanov, A. (2017). School Culture And Teacher Job Performance: A Comparative Analysis Of The Perception Of Teaching Staff in Private And Public Basic Schools In Ga South Municipality. British Journal of Education, 5(9), 108121. https://doi.org/10.1088/1751-8113/44/8/085201.

Wasito, E. (2021). Pengaruh Komitmen Organisasional terhadap Kinerja Guru Dimoderasi oleh Kepemimpinan Transformasional Kepala Sekolah dan Lingkungan Kerja di SMK Kabupaten Pemalang. Jurnal IImiah Ilmu Pendidikan, 4.

Yusof, H., Osman, M. N. A.-H., \& Noor, M. A. M. (2016). School Culture and Its Relationship with Teacher Leadership. International Journal of Academic Research in Business and Social Sciences, 6(11), 272-286. https://doi.org/10.6007/ijarbss/v6-i11/2396.

Zulkarnaen, Z. (2020). Pengaruh Budaya Sekolah, Gaya Kepemimpinan Transformasional, dan Motivasi Kerja Terhadap Kinerja Guru SMK. Jurnal Akuntabilitas Manajemen Pendidikan, 8(2), 175-185. https://doi.org/10.21831/jamp.v8i2.33867. 